\section{An examination of certain antecedents of social entrepreneurial intentions among Mexico residents}

\author{
Judith Cavazos-Arroyo \\ Popular Autonomous University of Puebla State (UPAEP), \\ Postgraduate Interdisciplinary Center, Puebla, Mexico \\ Rogelio Puente-Díaz \\ Anáhuac University, Department of Business and Economics, Mexico \\ Nivedita Agarwal \\ University of Erlangen-Nuremberg, Chair of Information \\ Systems I, Nuremberg, Germany
}

\begin{abstract}
Purpose - The purpose of our investigation is threefold. First, we assess the role of sustainable and social values as precursors of social innovation orientation, while taking into account interests as to financial returns. Second, we examine the role of social innovation orientation as an antecedent of a social entrepreneurship attitude. Third, we examine how attitude, subjective norms and entrepreneurship self-efficacy influence intentions of beginning a social entrepreneurship venture among Mexico residents.
\end{abstract}

Design/methodology/approach - We conducted 745 surveys among low-income Mexico residents who expressed interest in initiating a social entrepreneurship venture. We used structural equation modeling to test the hypothesized model.

Findings - Results showed the positive influence of social values on social innovation orientation, while taking into account the influence of financial interests. Social innovation orientation, an attitude toward social entrepreneurship, entrepreneurial self-efficacy and subjective norms were identified as positive predictors of social entrepreneurial intentions.

Originality/value - The paper provides useful information about the importance of values to understanding social innovation orientation and social entrepreneurship intentions.

Keywords - Intentions; values; social entrepreneurship; low income; developing countries.
Received on

03/31/2016

Approved on

$11 / 21 / 2016$

\section{Responsible editor:}

Prof. Dr. Francisco Diez Martin

Evaluation process:

Double Blind Review 


\section{Introduction}

Research on entrepreneurship intentions has increased dramatically over recent years. One literature review identified more than 400 publications on the role of intentions in the entrepreneurial process (Liñán \& Fayolle, 2015). Yet even though it is a widely researched topic, there are still gaps that empirical research should address. First, empirical literature focuses mainly on general entrepreneurship as opposed to more specific types such as social entrepreneurship intentions (Liñán \& Fayolle, 2015). Second, while the examination of specific subsamples has emerged, scant attention has been given to the social entrepreneurship intentions of individuals with low socio-economic status (Liñán \& Fayolle, 2015). Socio-economic status might be a proxy of a social context likely to influence the social entrepreneurial process (Fayolle \& Liñán, 2014). Third, while we have learned a lot about the role of intentions in the entrepreneurial process, we know less about the role of values as possible antecedents of an entrepreneurial attitude within the theoretical framework of intentions (Fayolle, Liñán, \& Moriano, 2014). This represents a significant shortcoming given that attitudes are strong predictors of intentions (Ajzen, 1991). Hence, the purpose of our investigation is threefold. First, we assess the role of sustainable and social values as precursors of social innovation orientation, while taking into account interests as to financial returns. Second, we examine the role of social innovation orientation as an antecedent of a social entrepreneurship attitude. Third, we examine how attitude, subjective norms, and entrepreneurship self-efficacy influence intentions of beginning a social entrepreneurship venture among Mexico residents with a low socio-economic status. In order to accomplish our research goals, we first discuss the nature of social entrepreneurship and its connection to the context of our investigation, followed by a discussion about the importance of values as antecedents to the development of social innovation orientation. We then examine the role social innovation orientation plays within the framework of the theory of planned behavior, by suggesting that its influence is exerted through a social entrepreneurship attitude. Last, we briefly review how social entrepreneurship attitude, subjective norms, and entrepreneurial self-efficacy serve as antecedents to the intention of engaging in a social venture in the future.

\section{I.I The nature of social entrepreneurship}

Although there is no consensus about the definition of social entrepreneurship (Trexler, 2008), a common element among the various existing definitions is the search for solutions to social problems. Hence, social entrepreneurs identify business opportunities in social problems that require solutions. The examination of social entrepreneurship has increased significantly over recent years (Svensson, 2014) as an alternative to alleviate many existing social problems. We adopt a broad definition that includes individuals or organizations involved in entrepreneurial activities to solve economic, social or/and environmental problems (Germak \& Singh, 2010; Short, Moss, \& Lumpkin, 2009; Zahra, Gedajlovic, Neubaum, \& Shulman, 2009). Essentially, social entrepreneurship is a benevolent attitude towards sharing with others (Guzmán \& Trujillo, 2008), highlighting the prevalence of a social mission, innovation and the role of an earned income (Lepoutre, Justo, Terjesen, \& Bosma, 2013).

Nicholls and Cho (2006) propose three key elements to constructing a social enterprise: socializing through social and environmental approaches, innovation and market orientation, especially when operating in commercial markets under the expectation of generating profits through the differentiation of social values. Traditionally, social entrepreneurs develop products and services that make basic, still unfulfilled human needs a priority. They strive towards promoting social change and enhancing the social status of customers (Lepoutre et al., 2013).

Even though social entrepreneurial efforts are relevant for most countries, they are 
particularly relevant for developing countries such as Mexico, for several reasons: 1) More than half of its population is poor (Sigma, 2013); 2) People do not have access to fundamental services due to limited government social programs and philanthropy efforts (Chivas, 2014); 3) Whereas self-employment and employment in the informal economy represent alternatives to obtain income, especially among the poor, these jobs tend to offer low wages and no benefits to employees (Velázquez Torres, \& Domínguez Aguirre, 2015). Thus, social entrepreneurship has emerged as a legitimate solution to address some of these urgent social needs (Chivas, 2014).

One theoretical proposition suggests that social entrepreneurs should have particular personal attributes that reflect a determination to change society as a whole (Seelos \& Mair, 2005). Hence, one recommendation is to put more emphasis on the examination of values in entrepreneurial intention (Fayolle et al., 2014), and the development of models that increase our knowledge of this topic (Liñán, Santos, \& Fernández, 2011). For example, recent studies (Sastre-Castillo, Peris-Ortiz, \& Danvila-Del Valle, 2015) have found that values influence social entrepreneurial orientation. However, one research suggestion is to examine values in relation to the theory of planned behavior to increase our understanding of the formation of attitudes and how intentions are influenced. Similarly, another research suggestion is that more research is needed to understand how to implement innovative solutions and transform the lives of those at the base of the pyramid (Goyal, Sergi, \& Jaiswal, 2016), especially in developing countries.

\section{I.2 Values as antecedents of social innovation orientation}

From a motivational perspective, values are important since they influence the type of goals individuals decide to pursue (Roberts \& Robins, 2000; Schwartz, 1992). In order to understand social entrepreneurship intentions, we need to identify the type of values that define and energize social entrepreneurship (Fayolle et al., 2014). Social entrepreneurs differ from commercial entrepreneurs in that they not only seek financial benefits but also strive for social benefits (Nga \& Shamuganathan, 2010). Hence, one model suggests that, in addition to interest in financial returns, social entrepreneurs are characterized by having a social vision and valuing sustainability, two values that energize motivation for innovating in order to satisfy basic human needs (Nga \& Shamuganathan, 2010).

Social vision is a value reflecting a deep concern for offering fundamental services to deprived sectors of society. Hence, entrepreneurship efforts try not only to obtain a financial return but also focus on satisfying a basic human need that has been, to some extent, neglected by society. Social motives have become an important research issue (Boluk \& Mottiar, 2014), because it is through particular social values that social entrepreneurs identify, evaluate, and exploit opportunities that are transformed into social innovations, creating social wealth (Zahra et al., 2009). Social entrepreneurs get involved in activities with a social mission because they feel responsible for caring for certain issues or people (André \& Pache, 2016). The achievement of a social mission requires the development of values, capabilities, and skills that lead to innovative solutions to complex social problems (Pearce \& Doh, 2005).

Social vision involves a sense of destiny, by finding practical solutions to complex social problems despite limitations to innovate (Nga \& Shamuganathan, 2010). It implies an explicit and central social mission, how entrepreneurs perceive and consider opportunities to produce a positive impact (Dees, 1998), the commitment to design products and services with social value for the community, developing partnerships and interacting through social networks and co-creating value with customers (Sridharan \& Viswanathan, 2008). Social entrepreneurs aspire to be agents of social change (Sundar, 1996). They have a vision and are motivated to accomplish it 
through a process of continuous innovation rather than replicate existing practices or enterprises (Urban, 2010).

Hence, our first proposition is that social vision should guide individuals to seek opportunities to innovate in order to solve social problems. That is, social vision should increase individuals' tendency towards social innovation orientation. Social innovation orientation implies the desire to be an agent of social change who creates new solutions to social problems through capabilities, products, services, processes and/or technology with social value and the possibility to develop social collaborations (Altuna et al., 2015; Nga \& Shamuganathan, 2010). Thus, social innovation orientation is an essential characteristic of social entrepreneurship, because it involves the conceptualization, creation, and development of strategies to encourage social change. Thus, we propose the following hypothesis:

\section{H1: Social vision would have a positive effect on social innovation orientation.}

While social vision represents an important value, we suggest that a concern for sustainability might also be important. Sustainability is a value characterized by a genuine understanding and acknowledgement that individuals and business practices exist as a part of a global ecosystem and that entrepreneurship efforts have to consider the environment as an additional stakeholder (Nga \& Shamuganathan, 2010). Sustainable values are capable of guiding individuals to enact behaviors perceived as supportive of sustainability goals. They play a critical role in building a vision to develop social structures and institutions, learn, and adapt to new knowledge and generate actions in complex human-nature systems (Miller, 2013; Miller et al., 2014). Hence, sustainability values should also influence entrepreneurs' social innovation orientation. We test the following hypothesis:

H2: Sustainable values would have a positive effect on social innovation orientation.
Social innovation poses a dilemma for traditional firms, since they usually seek to maximize economic value and not social value (Altuna et al., 2015). Even social entrepreneurship initiatives often face tensions between creating social and economic value (Hervieux et al., 2010). However, hybrid entrepreneurs seek to strike a balance between social and financial returns (Dorado, 2006; Nga \& Shamuganathan, 2010) or between environmental, social and financial performance (Felder-Kuzu, 2009). Usually, successful social entrepreneurs obtain profits to cover costs, become self-sufficient, and recover the invested money, while creating social change and providing community value as well (Dees 1998; Yunus et al., 2010). Consequently, in social entrepreneurship, making profits represent a mean to an end: obtaining profits in order to reach a social end or goal (Alvord et al., 2004) with the use of innovative business models (Lehtinen et al., 2007). Thus, we propose the following hypothesis:

\section{H3: Financial return interest would have a positive effect on social innovation orientation}

As stated earlier, one suggestion is to include values within the framework of the theory of planned behavior, given that it is probably one of the most widely used models to examine intentions in entrepreneurship research (Liñán \& Fayolle, 2015).

\section{3 Theory of planned behavior}

The theory of planned behavior (Ajzen, 1991) postulates that one of the strongest determinants of behavior are behavioral intentions. In addition, this theoretical model proposes three antecedents of intentions: attitude towards behavior, subjective norm, and perceived behavioral control. Attitude towards behavior is influenced by the behavioral beliefs held by individuals. If behavioral beliefs suggest that positive outcomes might be obtained by engaging in a specific behavior, individuals would likely have 
a positive attitude towards that specific behavior. Subjective norms deal with the perceived support or lack of support provided by important others to engaging in the specific behavior of interest. Last, perceived behavioral control deals with how much control or confidence individuals have in their abilities to perform the behavior of interest. We use the theory of planned behavior (Ajzen, 1991) as our main theoretical framework, putting special emphasis on how social entrepreneurial attitudes are influenced. Specifically, we suggest that social entrepreneurial attitudes should be influenced by entrepreneurs' concern as to social problems, sustainability, and interest as to financial return. Even so, we propose that this influence should be indirect, through social innovation orientation.

Social entrepreneurial attitude deals with a personal judgment about the value, benefit, and favorability of entrepreneurship that affects the intention to step into a new venture (Ajzen, 2002). Attitudes reflect subjective perceptions (Minniti \& Nardone, 2007) and can help create a climate conducive of entrepreneurial developments (Gupta \& York, 2008). An important research question deals with what explains the formation of a positive attitude toward social entrepreneurship. We suggest that the answer lies in our understanding of social innovation orientation.

Some authors argue that innovation is one of the key features evaluated by entrepreneurs (Hisrich \& Peters, 1998) because it facilitates the transformation and success of organizations (Rosairo \& Potts, 2016). Similarly, researchers suggest that innovation can enhance attitudes toward entrepreneurship (Robinson, Stimpson, Huefner, \& Hunt, 1991; Soomro \& Shah, 2015). A study with small entrepreneurs in Sri Lanka found that, among other variables, innovation influenced entrepreneurial attitudes, suggesting that entrepreneurship represents a mean to escape poverty in developing countries (Rosairo \& Potts, 2016). Similarly, an investigation conducted with potential entrepreneurs (Soomro \& Shah, 2015) showed a positive but low relationship between innovation and attitudes toward entrepreneurship, suggesting the need for conducting additional empirical investigations. Hence, we test the following hypothesis:

\section{H4: Social innovation orientation would have a positive effect on social entrepreneurial attitude}

\section{H4.1: Social and sustainability values and interest on financial returns would influence social entrepreneurial attitude indirectly, through their influence of social innovation orientation.}

While testing the influence of a social entrepreneurial attitude on intentions might not represent a contribution, we cannot ignore this effect when testing our model. Examining individuals' attitudes could be useful in predicting behavior through their influence on entrepreneurship intentions (Carlson, 1985; Fishbein \& Ajzen, 1975; Segal, Borgia, \& Schoenfeld, 2005). Research has shown that beliefs, values, and attitudes can affect the decision to become an entrepreneur (Hayton \& Cacciotti, 2013). Similarly, several studies have shown a significant relationship between attitude and entrepreneurial intention (Ferreira, Raposo, Rodrigues, Dinis, \& Paço, 2012; Kautonen, Tornikoski, \& Kibler, 2011; Zapkau, Schwens, Steinmetz, \& Kabst, 2015). In addition, we also suggest that the influence of social innovation orientation on intentions is indirect, through social entrepreneurial attitudes. Hence, we test the following hypotheses:

\section{H5: Social entrepreneurial attitude would have a positive effect on social entrepreneurial intention.}

H5.1: Social innovation orientation would influence intentions indirectly, through social entrepreneurial attitude.

In order to test the complete model of the theory of planned behavior in the context 
of social entrepreneurship, we also assess the influence of subjective norms and entrepreneurial self-efficacy on intentions. We first discuss the role of subjective norms.

Subjective norms refer to beliefs coming from the social environment that significant social groups such as spouses, friends, parents or other family members expect from an individual as to performing or not certain behaviors (Ajzen, 1991; Montaño \& Kasprzyk, 2008). If individuals perceive that significant others approve certain behavior, they possibly intend to perform it (Armitage \& Conner, 2001). Subjective norms are determined by underlying normative or social beliefs and these can predict the intentions of individuals (Armitage \& Conner, 1999; Kurobuza, Orobia, \& George, 2011).

Even though the link between subjective norms and intentions is an important component of the theory of planned behavior, empirical research has produced somewhat inconclusive results. Whereas certain investigations have found that subjective norms are a significant yet weak predictor of intentions (Armitage \& Conner, 2001; Kautonen, Van Gelderen, \& Tornikoski, 2013; Luthje \& Franke, 2003), others have reported inconsistent results (Kautonen et al., 2011; Sommer \& Haug, 2011; Van Gelderen et al., 2008; Zapkau et al., 2015). Some researchers have concluded that subjective norms are strongly dependent on context (Hübner \& Kaiser, 2006; Legris, Ingham, \& Collerette, 2003). For example, whereas subjective norms do not explain intentions in individualistic cultures, the results are mixed and inconclusive in collectivistic cultures, suggesting the need for conducting additional empirical investigations (Zampetakis, Lerakis, Kafetsios, \& Moustakis, 2015). Thus, we test the following hypothesis:

H6: Subjective norms would have a positive effect on social entrepreneurial intention.

Even though we use the theory of planned behavior, we assess the influence of self-efficacy as opposed to behavioral control. Some researchers have argued that behavioral control and selfefficacy are almost synonymous (Fayolle et al., 2014), indicating that several researchers have replaced behavioral control with self-efficacy in their models (Krueger, Reilly, \& Carsrud, 2000). However, some might disagree with this proposition (Ajzen, 2002). Instead of trying to resolve this controversy, we focus on explaining why self-efficacy might be an important predictor of intentions.

Self-efficacy is a key aspect of social cognitive theory and refers to the beliefs in personal abilities to organize and execute actions required to produce certain achievements (Bandura, 1997). Although some researchers have conceptualized self- efficacy as a general trait (Boyd \& Vozikis, 1994; Markman, Balkin, \& Baron, 2002), others have focused on specific domains of self-beliefs associated with entrepreneurship (Chen, Green, \& Crick, 1998; Moriano, Palací, \& Morales, 2006). In the context of entrepreneurship, selfefficacy is conceptualized as entrepreneurial self-efficacy (ESE) and defined as the strength of a person's belief in her or his abilities to perform the roles and tasks required to be an entrepreneur (Boyd \& Vozikis, 1994; Chen et al., 1998). Self-efficacy is one of the fundamental prerequisites for potential entrepreneurs (Krueger \& Brazeal, 1994), given that in certain contexts most novice entrepreneurs do not have enough business experience (Luthans \& Ibrayeva, 2006). Results from empirical investigations have shown that self-efficacy is a predictor of entrepreneurial intention (Barbosa, Gerhardt, \& Kickul, 2007; Paço, Ferreira, Raposo, Rodrigues, \& Dinis, 2011; Shook \& Bratianu, 2008). Similarly, research has also shown that self-efficacy is one of the factors that best explain social entrepreneurship intentions (Urban \& Teise, 2015). Hence, we propose the following hypothesis:

H7: Entrepreneurial self-efficacy would have a positive effect on social entrepreneurial intention (see Figure 1 for a graphical representation of our hypothesis). 


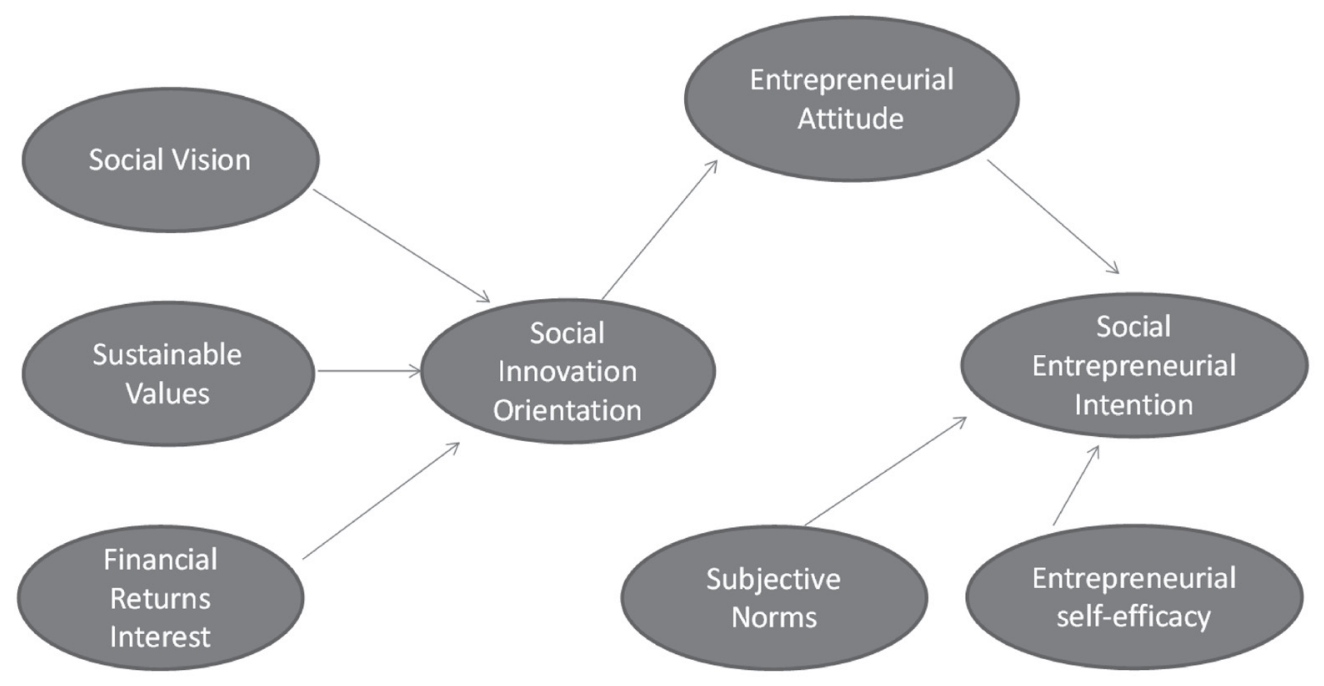

Figure 1. Graphical representation of hypotheses

In sum, the purpose of our investigation is threefold. First, we assess the role of sustainable and social values as precursors of social innovation orientation, while taking into account interest as to financial returns. Second, we examine the role of social innovation orientation as an antecedent of social entrepreneurship attitude. Third, we examine how attitude, subjective norms, and entrepreneurship self-efficacy influence the intentions of beginning a social entrepreneurship venture among Mexico residents with a low socioeconomic status.

\section{Method}

\section{I Participants}

Participants were $745(57.4 \%$ females and $41.2 \%$ males; $64.7 \%$ in the $18-25$ age group and $33.8 \%$ in the $26-35$ age group) potential entrepreneurs belonging to the lower socioeconomic segment in Puebla, Mexico. Altogether, 412 participants reported having a job and 305 were unemployed (28 didn't answer this question).

\subsection{Procedure}

Participants were approached outside of factories in industrial areas, public technical training centers, and two public universities. Hence, we used a sample of convenience to conduct face to face surveys. While we do not have a precise response rate, we might estimate that around $70 \%$ of the people approached accepted to answer our questionnaire. The questionnaire was structured in two parts, one covering socioeconomic filters and asking about the interest to start a social venture over the next two years (interviewer read a description/definition of social venture to participants in order for them to answer the question about interest/intention to start a social venture), and the second one including all the questionnaires. Each interview lasted between 15 and 20 minutes. The investigation obtained approval from the institutional human subjects committee.

\subsection{Measures}

All questionnaires used a seven-point Likert scale. The questionnaires used were (See Appendix for all items) the following:

Social Entrepreneurial Intention (Rantanen \& Toikko, 2014). The scale was modified to measure social entrepreneurial intention. The scale has four items tapping into the actual intention, the entrepreneurial willingness and the possibility of the career choice in entrepreneurship. The scores from the scale showed acceptable levels of internal consistency $\alpha=0.88$. 
Social Innovation Orientation (Nga \& Shamuganathan, 2010). This scale has eight items measuring social innovation orientation. The scores from the scale showed acceptable levels of internal consistency $\alpha=0.93$.

Social Vision (Nga \& Shamuganathan, 2010). This scale has eight items assessing social vision. The scores from the scale showed acceptable levels of internal consistency $\alpha=0.94$.

Sustainable Values (Nga \& Shamuganathan, 2010). The sustainability scale has six items. The scores from the scale showed acceptable levels of internal consistency $\alpha=0.89$.

Financial Return Interest (Nga \& Shamuganathan, 2010). This scale has six items measuring interest in financial returns. The scores from the scale showed acceptable levels of internal consistency $\alpha=0.86$.

Entrepreneurial attitude and subjective norms (Armitage \& Conner, 1999). These two questionnaires were adapted to the context of social entrepreneurship. The entrepreneurial attitude part has six items using a semantic differential scale and the subjective norm part, four items. Scores from both scales showed acceptable levels of internal consistency, $\alpha=0.90$ and $\alpha=0.86$, respectively.

Entrepreneurial self-efficacy. The Spanish version was adapted by Moriano et al. (2006) from the scale developed by DeNoble, Jung and Ehrlich (1999) which measures five dimensions of self-efficacy in the work domain. For our investigation, we focused only on one dimension that uses four items to assess beliefs about the ability to develop new products. The scores from the scale showed acceptable levels of internal consistency $\alpha=0.93$.

\section{Results}

Before testing our measurement and structural models, we examined the possibility that our results and conclusions might be distorted due to common method bias (Podsakoff, MacKenzie, \& Podsakoff, 2012; Podsakoff, MacKenzie, Podsakoff, \& Lee 2003). The examination of common method bias was pertinent, given that the answers to all our questions came from the same source. Following the guidelines suggested by Podsakoff and colleagues, we tested two measurement models. The first model was the original measurement model with all the latent variables and observed indicators. The second competing model was a model with all the original latent variables plus a common method factor with all the observed questionnaire items as indicators.

Results from the first measurement model showed an acceptable model fit, $\chi^{2}=2020.78$, $\mathrm{p}<.001(\mathrm{df}=667), \mathrm{RMSEA}=.05, \mathrm{CFI}=.94$, and TLI $=.94$. All factor loadings were significant and in the expected direction (ranging from .70 to .94). Some of the latent correlations were high (.79 was the highest), but below the suggested cut-off criterion of .85 (Brown, 2006) to establish discriminant validity (See Table 1 for descriptive statistics and latent correlations). Results from the measurement model with the common method factor also showed an acceptable model fit, $\chi^{2}=1931.45, \mathrm{p}<.001(\mathrm{df}=666)$, RMSEA $=.05$, CFI $=.95$, and TLI $=.94$. All factor loadings from the original measurement model remained significant while including the common method factor. In addition, the latent correlations were of similar magnitude with the highest value being .79. By comparing the results from both models, we concluded that the model fit was almost identical, suggesting that we could continue with the more parsimonious model without the common method factor ${ }^{1}$. 
Table 1

\section{Descriptive statistics and latent correlations}

\begin{tabular}{|c|c|c|c|c|c|c|c|c|}
\hline & Social vision & Sustainability & Financial return & Social Innovation & Subjective norms & Attitude & Self-efficacy & Intentions \\
\hline Social vision & 1 & & & & & & & \\
\hline Sustainability & 0.81 & 1 & & & & & & \\
\hline Financial return & 0.59 & 0.71 & 1 & & & & & \\
\hline Social Innovation & 0.72 & 0.70 & 0.60 & 1 & & & & \\
\hline Subjective norms & 0.55 & 0.55 & 0.56 & 0.69 & 1 & & & \\
\hline Attitude & 0.14 & 0.20 & 0.07 & 0.28 & 0.2 & 1 & & \\
\hline Self-efficacy & 0.54 & 0.55 & 0.56 & 0.73 & 0.62 & 0.20 & 1 & \\
\hline Intentions & 0.60 & 0.60 & 0.50 & 0.79 & 0.69 & 0.31 & 0.61 & 1 \\
\hline Mean & 4.95 & 5.18 & 5.23 & 5.05 & 4.70 & 5.85 & 5.07 & 4.99 \\
\hline $\mathrm{SD}$ & 1.30 & 1.16 & 1.15 & 1.28 & 1.53 & 1.10 & 1.44 & 1.43 \\
\hline
\end{tabular}

Results for the structural model showed an acceptable model fit, $\chi^{2}=2413.62, \mathrm{p}<.001(\mathrm{df}$ $=678)$, RMSEA $=.06$, CFI $=.93$, and TLI $=.92$. Examination of the individual parameters showed a significant influence of social vision values and financial return interest on social innovation orientation, $\gamma=.47 \mathrm{p}<.001$; and $\gamma=.27, \mathrm{p}<.001$, respectively, supporting hypothesis 1 and 3 . The influence of sustainable values was not significant, $\gamma=.13, \mathrm{p}=.16$, failing to support hypothesis 2. Social innovation orientation had a positive influence on social entrepreneurial attitude, $\beta=.28, \mathrm{p}<.001$, supporting hypothesis 4 . The effects of subjective norms, social entrepreneurial attitude, and entrepreneurial self-efficacy on social entrepreneurial intention were significant, $\gamma=.51, \mathrm{p}<.001 ; \beta=.18, \mathrm{p}<.001 ; \gamma=.27$, $\mathrm{p}<.001$, supporting hypotheses 5, 6 and 7 . Regarding indirect effects, results showed a positive influence of interest on financial returns and social vision on social entrepreneurship attitude, .07, $\mathrm{p}<.001$ and $.10, \mathrm{p}<.001$. The influence of sustainability values on social entrepreneurship attitude was not significant, $.04 \mathrm{p}=.17$. Last, the indirect influence of social innovation orientation on intentions was significant, .05 $\mathrm{p}<.001$.

As shown in Figure 2, our model proposed certain mediation effects. First, we constrained the influence of social vision, sustainable values, and financial return interest on social entrepreneurial attitude to be indirect, through its influence on social innovation orientation. Similarly, we constrained the influence of social innovation orientation on social entrepreneurial intention to be indirect, through its influence on social entrepreneurial attitude. Hence, we tested the feasibility of these mediation effects in one additional model allowing for direct effects and assessing the fit of the model.

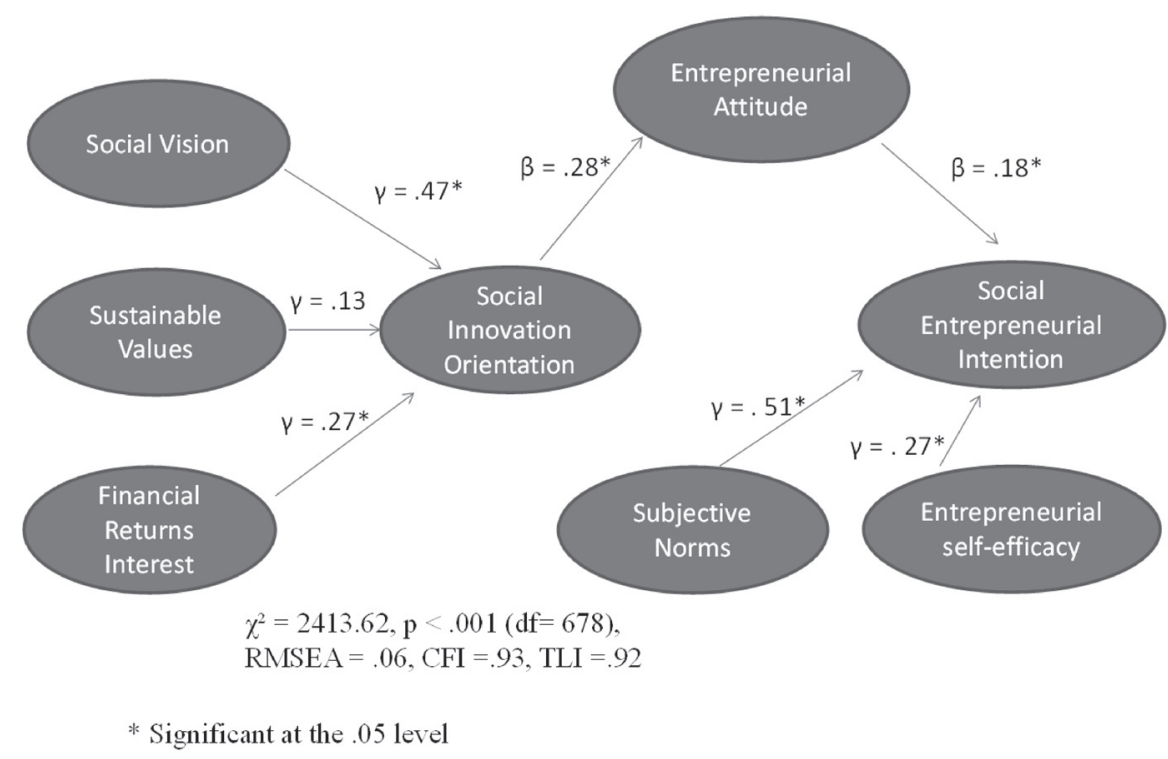

Figure 2. Summary of results 
We conducted an analysis allowing social vision, financial return interest, and sustainable values to have a direct influence on social entrepreneurial attitude and social innovation orientation to have a direct effect on intentions. Results showed an acceptable model fit, $\chi^{2}=2243.78, \mathrm{p}<.001(\mathrm{df}=674)$, RMSEA $=.06$, CFI $=.93$, and TLI $=.93$. By comparing the model with more and fewer constrains, the $\chi^{2}$ was significantly lower for the model with direct effects, $2413.62-2243.78$ $=169.84, \mathrm{p}<.001$. However, the chi-square difference test has been criticized because it is highly dependent on sample size (Preacher \& Hayes, 2008). An alternative was to examine the overall fit of the model, to determine if one would reach a different conclusion when assessing the fit of both models. By doing so, we could conclude that the fit of both models was almost identical with the same values for RMSEA, CFI and with a small difference in TLI. In addition, three of our indirect effects were significant, providing partial support for hypotheses 4.1 and 5.1. Hence, we decided to keep our parsimonious model to discuss results.

\section{Discussion}

The purpose of the present investigation was threefold. First, we examined the role of financial returns and sustainable and social values as antecedents of social innovation orientation. Second, we analyzed the role of social innovation orientation as a precursor of social entrepreneurship attitude. Third, we also examined how attitude, subjective norms, and entrepreneurship self-efficacy influence the intentions of starting a social entrepreneurship venture among Mexico residents with a low socioeconomic status. We found support for most of the hypothesis, but we failed to find support from the impact of sustainable values on social innovation orientation and on entrepreneurial attitude. We turned our attention towards the discussion of the theoretical and applied implications of our results.

\section{I Theoretical implications}

Our first hypothesis stated that social vision would have a positive effect on social innovation orientation. We found support for hypothesis 1 . Our results were consistent with a previous investigation that found social vision to be a significant predictor of social innovation orientation (Nga \& Shamuganathan, 2010; Sridharan \& Viswanathan, 2008). Through social values, social entrepreneurs identify, evaluate and exploit opportunities that could become innovative solutions to complex social problems.

However, we did not find support for hypothesis 2, which proposed the influence of sustainable values on social innovation orientation. Previous research has found that sustainable values were critical to create new knowledge and inventions (Miller, 2013; Osburg, 2013). We considered that the holistic sense of sustainable values makes social relevant innovation (Osburg, 2013), because they act as a driver and an engine of change. A possible explanation may be that in current Mexican context, sustainability is a new movement that, to be effective, requires a change in the values of marketplace stakeholders. Therefore, we recommended developing mechanisms to reduce the importance attached to material values and emphasize values that increase individual, collective, and global welfare (Cavazos \& Puente, 2015).

Our results also showed that financial return interest was a significant antecedent of social innovation orientation, supporting hypothesis 3. Many social entrepreneurs seek to obtain financial returns but are also energized by social motives that lead to the generation of social innovations to create social welfare and better conditions for underprivileged groups (Prahalad, 2004; Zahra et al., 2009). Other investigations conducted in emergent countries have found similar results. For example, research in India among knowledge rich-economically poor entrepreneurs have shown their willingness and ability to create innovations for other poor people (Gupta, 2012). 
Similarly, our fourth hypothesis proposed a positive effect of social innovation orientation on social entrepreneurial attitude and our results showed this positive relationship. Hence, hypothesis 4 was supported. Our results were consistent with previous investigations conducted with small entrepreneurs in Sri Lanka (Rosairo \& Potts, 2016) and with potential entrepreneurs in Pakistan (Soomro \& Shah, 2015). It seems that the desire to create news solutions to social problems improve attitudes toward social entrepreneurship.

Conversely, we only found partial support for an extension of hypothesis 4 (labeled as 4.1), in which we proposed an indirect effect of social and sustainability values and interest on financial returns on social entrepreneurial attitude, through their influence of social innovation orientation. We found support for the indirect influence of social vision and financial returns on social entrepreneurial attitude, but we did not find support for the indirect influence of sustainable values. Entrepreneurial attitude in social entrepreneurs is based on finding opportunities in social needs and in critical situations (Sastre-Castillo et al., 2015). This kind of attitude could be driven indirectly by how potential entrepreneurs appropriate and commit to a social mission and by the pursuit profit objectives. This is consistent with other studies in developing countries, where social entrepreneurs showed interest in profitability and in developing social innovations (Bhatt, Ahmad, \& Roomi, 2016). Conversely, sustainability values did not influence social entrepreneurial attitude indirectly. Awareness of the benefits of sustainability and its impact on social entrepreneurial attitudes through innovation requires knowledge, education, sensibility, and multilateral networks to face social, economic and environmental challenges (Rosairo \& Potts, 2016; Windrum, Schartinger, Rubalcaba, Gallouj, \& Toivonen, 2016). Hence, it might be that the entrepreneurs in our sample had not yet internalized the value of sustainability. Regarding hypothesis 5, we found support for the postulate that social entrepreneurial attitude would have a positive effect on social entrepreneurial intention. This result was consistent with many other investigations that have found that individual attitudes predict entrepreneurial intentions (Carlson, 1985; Ferreira et al., 2012; Hayton \& Cacciotti, 2013; Kautonen et al., 2011; Segal et al., 2005; Zapkau et al., 2015). In addition, we found that social innovation orientation influenced intentions indirectly, through social entrepreneurial attitude. The motivation to be a social creator through innovative processes is a key feature among social entrepreneurs (Hisrich \& Peters, 1998). Through a positive social entrepreneurial attitude, it is possible to drive social innovators to have the desire and aspiration to initiate a social venture in the future, encouraging social change (Prieto, Phipps, \& Friedrich, 2012).

Consistent with previous investigations examining entrepreneurial intentions, we found support for hypotheses 6 and 7, which stated that subjective norms and entrepreneurial selfefficacy would have a positive effect on social entrepreneurial intention. Our findings showed that subjective norms were the strongest predictor of social entrepreneurial intention. This could be explained if we take into account context and cultural variables (Hübner \& Kaiser, 2006). Specifically, Mexico is characterized by being a highly collectivistic culture. Empirical research has shown that cultures with high levels of collectivism tend to give higher value to subjective norms when decision-making (Dawkins, Jamali, Karam, Lin, \& Zhao, 2014), where the opinions of family and friends act as a social support mechanism that approves or disapproves the social entrepreneurial intention. Similarly, we found a positive effect of entrepreneurial self-efficacy on social entrepreneurial intention. Our results were consistent with other empirical investigations, supporting the important role of self-efficacy as a predictor of both entrepreneurial intentions (Paço et al., 2011; Shook \& Bratianu, 2008) and social entrepreneurial intentions (Urban \& Teise, 2015). Some researchers (Krueger \& Brazeal, 1994; 
Urban \& Teise, 2015) consider self-efficacy as a fundamental factor among potential and novice entrepreneurs.

\subsection{Applied implications}

From an applied perspective, our findings might have several implications. First, developing countries such as Mexico have to promote the creation of social entrepreneurial alternatives inserted in the formal economy to reduce inequality and improve the quality of life of the poor. Empowering low socio-economic potential entrepreneurs implies the creation of models driving values to develop frugal or incremental innovations aimed at forming a positive attitude towards social entrepreneurship. Social vision represents the standards of an individual's ideological orientation, made inter-subjectively (Arikan \& Bloom, 2015; Tsirogianni \& Gaskel, 2011), that could be reinforced and used to promote the development of new social ventures.

This is particularly important for Mexico, since research shows that Latin America and the Caribbean have not shown significant advances in their innovation indexes (Dutta, Lanvin, \& Wunsch-Vincent, 2015), which is manifest in a small social innovation sector (Jáuregui, 2013). This lack of progress is troublesome, since the investment in social innovation might represent an opportunity to reduce the significant gaps between the way that the traditional businesses operate, and an opportunity to better understand the needs of the community in order to select the best partners to act as agents of social change. Hence, in order to facilitate social entrepreneurial intentions, governments, associations, startups and consolidated enterprises need to co-invest, facilitate training, share their knowledge and contribute to overcoming the barriers that limit social entrepreneurs.

\subsection{Limitations and future research}

Our investigation presented several limitations. First, we used a sample of convenience, which limits our ability to generalize our findings to the population of low income potential social entrepreneurs in Mexico. Future research might want to use more representative and diverse samples to increase external validity. Second, we used a cross-sectional design that limits the ability to understand how entrepreneurial intentions unfold, and to understand if intentions are actually realized. Future investigations might want to use longitudinal designs to examine if intentions are actually realized. Lastly, considering the possibility of common method bias, given that the measurement of all our variables came from the same source, we suggest that future research should try to use different sources of information.

In sum, our investigation showed the important role that social vision values and financial return interest play in energizing social innovation and how they are closely related to the formation of a social entrepreneurial attitude. In addition, social entrepreneurial intention was explained by subjective norms, attitude toward social entrepreneurship, and selfefficacy. Moreover, social entrepreneurial attitude mediated the influence of social innovation orientation on the intentions of engaging in a social entrepreneurship venture in the near future among participants from Mexico.

\section{Note}

${ }^{1}$ We thank one of the reviewers for raising the issue of common method bias

\section{References}

Ajzen, I. (1991). The theory of planned behavior. Organizational Behavior and Human Decision Process, 50(2), 179-211.

Ajzen, I. (2002). Perceived behavioural control, self-efficacy, locus of control and the theory of planned behaviour. Journal of Entrepeneurship Behaviour and Research, 32(4), 28-50.

Altuna, N., Contri, A. M., Dell'Era, C., Frattini, F., \& Maccarrone, P. (2015). Managing social innovation in for-profit organizations: The 
case of Intesa Sanpaolo. European Journal of Innovation Management, 18(2), 258-280.

Alvord, S. H., Brown, L. D., \& Letts, C. W. (2004). Social entrepreneurship and societal transformation an exploratory study. The Journal of Applied Behavioral Science, 4O(3), 260-282.

André, K., \& Pache, A. C. (2016). From caring entrepreneur to caring enterprise: Addressing the ethical challenges of scaling up social enterprises. Journal of Business Ethics, 133(4), 659-675.

Arikan, G., \& Bloom, P. B. N. (2015). Social values and cross-national differences in attitudes towards welfare. Political Studies, 63(2), 431-448.

Armitage, C. J., \& Conner, M. (1999). Predictive validity of the theory of planned behavior: the role of questionnaire format and social desirability. Journal of Community and Applied Social Psychology, 9(4), 261-272.

Armitage, C. J., \& Conner, M. (2001). Efficacy of the theory of planned behaviour: A meta-analytic review. British Journal of Social Psychology, 40(4), 471-499.

Bandura, A. (1997). Self-efficacy: The exercise of control. New York, NY: W.H. Freeman.

Barbosa, S., Gerhardt, M., \& Kickul, J. (2007). The role of cognitive style and risk preference on entrepreneurial self-efficacy and entrepreneurial intentions. Journal of Leadership and Organizational Studies, 13(4), 86-104.

Bhatt, P., Ahmad, A. J., \& Roomi, M. A. (2016). Social innovation with open source software: User engagement and development challenges in India. Technovation, 52-53, 28-39.
Boluk, K. A., \& Mottiar, Z. (2014). Motivations of social entrepreneurs: Blurring the social contribution and profits dichotomy. Social Enterprise Journal, 10(1), 53-68.

Boyd, N. G., \& Vozikis, G. S. (1994). The influence of self-efficacy on the development of entrepreneurial intentions and actions. Entrepreneurship Theory and Practice, 18, 63-77.

Carlson, S. D. (1985). Consistency of attitude components: A new proposal for an old problem (Master dissertation). Brigham Young University, Provo, Utah, EUA.

Cavazos Arroyo, J., \& Puente-Díaz, R. (2015). Posibilidades de un consumo sustentable en México. In B. Pérez-Armendáriz, J. Cavazos Arroyo, G. Rosano Ortega, \& M. A. Lagunes Pérez (Eds.), La sustentabilidad en México: Un nuevo planteamiento ante el paradigma (pp. 21-42). Puebla, MX: UPAEP.

Chen, C. C., Green, P. G., \& Crick, A. (1998). Does entrepreneurial self-efficacy distinguish entrepreneurs from managers? Journal of Business Venturing, 13(4), 295-316.

Chivas (2014). (Redefining) Success in a changing world. Retrieved from https://www. theventure.com/bundles/appmain/pdf/ chivas_report.pdf

Dawkins, C. E., Jamali, D., Karam, C., Lin, L., \& Zhao, J. (2014). Corporate social responsibility and job choice intentions: A cross-cultural analysis. Business and Society, 55(6), 1-35.

Dees, J. G. (1998). The meaning of "social entrepreneurship”. Retrieved from https://csistg. gsb.stanford.edu/sites/csi.gsb.stanford.edu/ files/TheMeaningofsocialEntrepreneurship. pdf

DeNoble, A. F., Jung, D., \& Ehrlich, S. B. (1999). Entrepreneurial self-efficacy: The 
development of a measure and its relationship to entrepreneurial action. In R. D. Reynolds, W. D. Bygrave, S. Manigart, C. M. Mason, G. D. Meyer, H. J. Sapienze, \& K. G. Shaver (Eds.), Frontiers of entrepreneurship research (pp. 73-78). Waltham, MA: P\& R Publication Inc

Dorado, S. (2006). Social entrepreneurial ventures: Different values so different process of creation, no? Journal of Developmental Entrepreneurship, 11(4), 319-343.

Dutta, S., Lanvin, B., \& Wunsch-Vincent, S. (2015). The global innovation index 2015: Effective innovation policies for development. Geneva: Johnson Cornell University, INSEAD and WIPO.

Fayolle, A., \& Liñán, F. (2014). The future of research on entrepreneurial intentions. Journal of Business Research, 67(5), 663-666.

Fayolle, A., Liñán, F., \& Moriano, J. A. (2014). Beyond entrepreneurial intentions: values and motivations in entrepreneurship. International Entrepreneurship and Management Journal, 10(4), 679-689.

Felder-Kuzu, N. (2009). Microfinance and beyond: Introducing microfranchising and social businesses. USA: Author.

Ferreira, J., Raposo, M. L., Rodrigues, R. G., Dinis, A., \& Paço, A. D. (2012). A model of entrepreneurial intention: an application of the psychological and behavioral approaches. Journal of Small Business and Enterprise Development, 19(3), 424-440.

Fishbein, M., \& Ajzen, I. (1975), Belief, attitude, intentions and behaviour: An introduction to theory and research. Boston: Addison-Wesley.

Germak, A. J., \& Singh, K. K. (2010). Social entrepreneurship: Changing the way social workers do business. Administration in Social Work, 34(1), 79-95.
Goyal, S., Sergi, B. S., \& Jaiswal, M. (2016). Understanding the challenges and strategic actions of social entrepreneurship at base of the pyramid. Management Decision, 54(2), $1-33$.

Gupta, A. K. (2012). Innovations for the poor by the poor. International Journal of Technological Learning, Innovation and Development, 5(12), 28-39.

Gupta, V. K., \& York, A. S. (2008). Attitudes toward entrepreneurship and small business. Journal of Enterprising Communities: People and Places in the Global Economy, 2(4), 348366.

Guzmán, A., \& Trujillo, M. A. (2008). Emprendimiento social: Revisión de literatura. Estudios Gerenciales, 24(109), 105-125.

Hayton, J. C., \& Cacciotti, G. (2013). Is there an entrepreneurial culture? A review of empirical research. Entrepreneurship and Regional Development, 25(9-10), 708-731.

Hervieux, C., Gedajlovic, E., \& Turcotte, M. F. B. (2010). The legitimization of social entrepreneurship. Journal of Enterprising Communities: People and Places in the Global Economy, 4(1), 37-67.

Hisrich, R. D., \& Peters, M. P. (1998). Entrepreneurship. New York, NY: McGrawHill.

Hübner, G., \& Kaiser, F. G. (2006). The moderating role of the attitude-subjective norms conflict on the link between moral norms and intention. European Psychologist, 11(2), 99-109.

Jáuregui, L. M. (2013). Money is never enough. Retrieved from http://ssir.org/articles/entry/ money_is_never_enough 
Kautonen, T., Tornikoski, E. T., \& Kibler, E. (2011). Entrepreneurial intentions in the third age: The impact of perceived age norms, Small Business Economics, 37(2), 219-234.

Kautonen, T., Van Gelderen, M., \& Tornikoski, E. T. (2013). Predicting entrepreneurial behaviour: A test of the theory of planned behavior. Applied Economics, 45(6), 697-707.

Krueger, N. F., \& Brazeal, D. V. (1994). Entrepreneurial potential and potential entrepreneurs. Entrepreneurship Theory and Practice, 18(3), 91-104.

Krueger, N., Reilly, M., \& Carsrud, A. (2000). Competing models of entrepreneurial intentions. Journal of Business Venturing, 15(5/6), 411-432.

Kurobuza, E., Orobia, L., \& George, B. P. (2011). Development of a conceptual model to understand international social entrepreneurship and its application in the Ugandan context. Journal of International Entrepreneurship, 9(4), 282-298.

Legris, P., Ingham, J., \& Collerette, P. (2003). Why do people use information technology? A critical review of the technology acceptance model. Information \& Management, 40(3), 191-204.

Lehtinen, U., Paloniemi, K., Pajari, S., \& Poikela, K. (2007). Social entrepreneurship in the field of recycling: how to develop profitable business with social impacts? Proceedings of the ICSB World Conference, June, Turku, Finland, 52. Retrieved from http://www.researchgate.net/profile/ Ulla_Lehtinen/publication/255574243_ SOCIAL_ENTREPRENEURSHIP IN_THE_FIELD_OF_RECYCLING_ HOW_TO_DEVELOP_PROFITABLE_ BUSINESS_WITH_SOCIAL_IMPACTS/ links/02e7e5207afcfe9b2f000000.pdf
Lepoutre, J., Justo, R., Terjesen, S., \& Bosma, N. (2013). Designing a global standardized methodology for measuring social entrepreneurship activity: The Global Entrepreneurship Monitor social entrepreneurship study. Small Business Economics, 40(3), 693-714.

Liñán, F., \& Fayolle, A. (2015). A systematic literature review on entrepreneurial intentions: Citation, thematic analyses, and research agenda. International Entrepreneurship and Management Journal, 11(4), 907-933.

Liñán, F., Santos, F. J., \& Fernández, J. (2011). The influence of perceptions on potential entrepreneurs. International Entrepreneurship and Management Journal, 7(3), 373-390.

Luthans, F., \& Ibrayeva, E. (2006). Entrepreneurial self-efficacy in central Asian transition economies: Quantitative and qualitative analyses. Journal of International Business Studies, 37(1), 92-110.

Luthje, C., \& Franke, N. (2003). The making of an entrepreneur: Testing a model of entrepreneurial intent among engineering students at MIT. R\&D Management, 33(2), $135-147$.

Markman, G. D., Balkin, D. B., \& Baron, R. A. (2002). Inventors and new venture formation: The effects of general self-efficacy and regretful thinking. Entrepreneurship Theory and Practice, 27(2), 149-165.

Miller, T. R. (2013). Constructing sustainability science: Emerging perspectives and research trajectories. Sustainability science, 8(2), 279293.

Miller, T. R., Wiek, A., Sarewitz, D., Robinson, J., Olsson, L., Kriebel, D., \& Loorbach, D. (2014). The future of sustainability science: A solutions-oriented research agenda. Sustainability Science, 9(2), 239-246. 
Minniti, M., \& Nardone, C. (2007). Being in someone else's shoes: The role of gender in nascent entrepreneurship. Small Business Economics, 28(2), 223-238.

Montaño, D. E., \& Kasprzyk, D. (2002). The theory of reasoned action and the theory of planned behavior. In K. Glanz, B. K. Rimer, \& F. M. Lewis (Eds.), Health behavior and health education: Theory, research and practice (pp. 67-98). San Francisco, CA: Jossey-Bass.

Moriano, J. A., Palací, F. J., \& Morales, J. F. (2006). Adaptación y validación en España de la escala de autoeficacia emprendedora. Revista de Psicología Social, 21(1), 51-64.

Nga, J. K., \& Shamuganathan, G. (2010). The influence of personality traits and demographic factors on social entrepreneurship start up intentions. Journal of Business Ethics, 95(2), 259-282.

Nicholls, A., \& Cho, A. H. (2006). Social entrepreneurship: The structuration of a field. In A. Nicholls (Ed.), Social entrepreneurship: New models of sustainable change (pp. 99118). New York, NY: Oxford University Press.

Osburg, T. (2013). Social innovation to drive corporate sustainability. In T. Osburg, \& R. Schmidpeter (Eds.), Social innovation: Solutions for a sustainable future (pp. 13-22). Berlin Heidelberg: Springer.

Paço, A. M. F., Ferreira, J. M., Raposo, M., Rodrigues, R. G., \& Dinis, A. (2011). Behaviors and entrepreneurial intention: Empirical findings about secondary students. Journal of International Entrepreneurship, 9(1), 20-38.

Pearce, J. A., \& Doh, J. P. (2005). The High Impact of Collabor. MIT Sloan Management Review, 46(3), 29-40.
Podsakoff, P. M., MacKenzie, S. B., \& Podsakoff, N. P. (2012). Sources of method bias in social science research and recommendations on how to control it. Annual Review of Psychology, 63, 539-569.

Podsakoff, P. M., MacKenzie, S. B., Podsakoff, N. P., \& Lee, J. Y. (2003). The mismeasure of man (agement) and its implications for leadership research. The Leadership Quarterly, 14(6), 615-656.

Prahalad, C. K. (2004). Fortune at the bottom of the pyramid: Eradicating poverty through profits. Upper Saddle River, NJ: Prentice Hall.

Preacher, K. J., \& Hayes, A. F. (2008). Contemporary approaches to assessing mediation in communication research. In A. F. Hayes, M. D. Slater, \&d L. B. Snyder (Eds), The Sage sourcebook of advanced data analysis methods for communication research (pp. 13-54). Thousand Oaks, CA: Sage Publications.

Prieto, L., Phipps, S. T. A., \& Friedrich, T. L. (2012). Social entrepreneur development: An integration of critical pedagogy, the theory of planned behavior and the ACS Model. Academy of Entrepreneurship Journal, 18(2), $1-15$.

Rantanen, T., \& Toikko, T. (2014). Entrepreneurship, social welfare, and cultural values: Young people's social attitudes in Finland, Advances in Business-Related Scientific Research Journal, 5(1), 13-24.

Roberts, B. W., \& Robins, R. W. (2000). Broad dispositions, broad aspirations: The intersection of personality traits and major life goals. Personality and Social Psychology Bulletin, 26(10), 1284-1296.

Robinson, P. B., Stimpson, D. V., Huefner, J. C., \& Hunt, H. K. (1991). An attitude approach to the prediction of entrepreneurship. 
Entrepreneurship theory and practice, 15(4), 13-31.

Rosairo, H. R., \& Potts, D. J. (2016). A study on entrepreneurial attitudes of upcountry vegetable farmers in Sri Lanka. Journal of Agribusiness in Developing and Emerging Economies, 6(1), 39-58.

Sastre-Castillo, M. A., Peris-Ortiz, M., \& Danvila-Del Valle, D. (2015). What is different about the profile of the social entrepreneur? Nonprofit Management and Leadership, 25(4), 349-369.

Schwartz, S. H. (1992). Universals in the content and structure of values: Theoretical advances and empirical tests in 20 countries. Advances in Experimental Social Psychology, 25, 1-65.

Seelos, C., \& Mair, J.(2005). Social entrepreneurship: Creating new business models to serve the poor. Business Horizons, 48(3), 241-246.

Segal, G., Borgia, D., \& Schoenfeld, J. (2005). The motivation to become an entrepreneur. International Journal of Entrepreneurial Behaviour and Research, 11(1), 42-57.

Shook, C. L., \& Bratianu, C. (2010), Entrepreneurial intent in a transitional economy: An application of the theory of planned behavior to Romanian students. International Entrepreneurship Management Journal, 6(3), 231-347.

Short, J. C., Moss, T. W., \& Lumpkin, G. T. (2009). Research in social entrepreneurship: Past contributions and future opportunities. Strategic Entrepreneurship Journal, 3(2), 161-194.

Sigma (2013). Mercados potenciales: El Mercado de los consumidores mexicanos por niveles socioeconómicos. México: Sigma.
Sommer, L., \& Haug, M. (2011). Intention as a cognitive antecedent to international entrepreneurship: Understanding the moderating roles of knowledge and experience. International Entrepreneurship Management Journal, 7(1), 111-142.

Soomro, B. A., \& Shah, N. (2015). Developing attitudes and intentions among potential entrepreneurs. Journal of Enterprise Information Management, 28(2), 304-322.

Sridharan, S., \& Viswanathan, M. (2008). Marketing in subsistence marketplaces: Consumption and entrepreneurship in a South Indian context. Journal of Consumer Marketing, 25(7), 455-462.

Sundar, P. (1996). Women and philanthropy in India. Voluntas: International Journal of Voluntary and Nonprofit Organizations, 7(4), 412-427.

Svensson, C. F. (2014). Making money is not an end in itself: Creating meaningfulness among employees of social enterprises. Antipod. Revista de Antropología y Arqueología, (18), 241-255.

Trexler, J. (2008). Social entrepreneurship as an algorithm: Is social enterprise sustainable? Emergence: Complexity and Organization, 3(10), 65-85.

Tsirogianni, S., \& Gaskell, G. (2011). The role of plurality and context in social values. Journal for the Theory of Social Behaviour, 41(4), 441-465.

Urban, B. (2010). Creating value and innovation through social entrepreneurship. In B. Urban (Ed.), Frontiers in Entrepreneurship (pp.115138). London: Springer.

Urban, B., \& Teise, H. (2015). Antecedents to social entrepreneurship intentions: An empirical study in South Africa. Management 
Dynamics: Journal of the Southern African Institute for Management Scientists, 24(2), 36-52.

Van Gelderen, M., Brand, M., Van Praag, M., Bodewes, W., Poutsma, E., \& Van Gils, A. (2008). Explaining entrepreneurial intentions by means of the theory of planned behavior. Career Development International, 13(6), 538-559.

Velázquez Torres, J. C., \& Domínguez Aguirre, L. R. (2015). Trabajo informal y economía informal en México. Un acercamiento teórico. European Scientific Journal, 11(4), 231-251.

Windrum, P., Schartinger, D., Rubalcaba, L., Gallouj, F., \& Toivonen, M. (2016). The cocreation of multi-agent social innovations: a bridge between service and social innovation research. European Journal of Innovation Management, 19(2), 150-166.
Yunus, M., Moingeon, B., \& Lehmann-Ortega, L. (2010). Building social business models: Lessons from the Grameen experience. Long Range Planning, 43(2), 308-325.

Zahra, S. A., Gedajlovic, E., Neubaum, D. O., \& Shulman, J. M. (2009). A typology of social entrepreneurs: Motives, search processes and ethical challenges. Journal of Business Venturing, 24(5), 519-532.

Zampetakis, L. A., Lerakis, M., Kafetsios, K., \& Moustakis, V. S. (2015). The moderating role of anticipated affective ambivalence in the formation of entrepreneurial intentions. International Entrepreneurship and Management Journal, 6, 1-13.

Zapkau, F. B., Schwens, C., Steinmetz, H., \& Kabst, R. (2015). Disentangling the effect of prior entrepreneurial exposure on entrepreneurial intention. Journal of Business Research, 68(3), 639-653. 


\section{Appendix - Development of measurement constructs}

\begin{tabular}{|c|c|}
\hline Social vision (Nga \& Shamuganathan, 2010) & Social Innovation Orientation (Nga \& Shamuganathan, 2010) \\
\hline I am clearly able to identify a social need & I am proactive in identifying social opportunities \\
\hline I am able to create a clear social vision & I am able to see risks as opportunities to create social value \\
\hline I am strongly committed to a social vision & I am able to create social value through goods/services \\
\hline I take a focused stand on social issues & $\begin{array}{l}\text { I am able to deliver sustainable advantages through innovative goods } \\
\text { and services }\end{array}$ \\
\hline I am determined to meet a social need & $\begin{array}{l}\text { I am able to create better social value compared to normal } \\
\text { entrepreneurs }\end{array}$ \\
\hline I am determined to be an agent of social change & $\begin{array}{l}\text { I am able to deliver sustainable advantage through innovative goods } \\
\text { and service }\end{array}$ \\
\hline I am not easily distracted to pursue other non-social issues & I am a flexible individual \\
\hline I have strong motivation to defend a social need & I am an innovative individual \\
\hline Social entrepreneurial intention (Rantanen \& Toikko, 2014) & $\begin{array}{l}\text { Entrepreneurial self-efficacy: ability to develop new products } \\
\text { (Moriano et al., 2006) }\end{array}$ \\
\hline $\begin{array}{l}\text { If I could freely choose, I'd rather be a social entrepreneur than } \\
\text { an employee }\end{array}$ & I recognize new market opportunities for new products and services \\
\hline My aim is to become a social entrepreneur in the future & I discover new ways to improve existing products \\
\hline I am going to make a living as a social entrepreneur & I design product ideas that solve common problems \\
\hline For me, social entrepreneurship is a probable career choice & $\begin{array}{l}\text { I want to develop products that meet the uncovered needs of } \\
\text { customers }\end{array}$ \\
\hline Sustainable Values (Nga \& Shamuganathan, 2010) & Financial Return Interest (Nga \& Shamuganathan, 2010) \\
\hline I am environmentally friendly & $\begin{array}{l}\text { I believe that making a profit is the main reason for the existence of a } \\
\text { business }\end{array}$ \\
\hline I improve quality of life in the long run & I agree to sell goods and services for a profit \\
\hline I improve a long term social need & I agree on maximizing financial wealth \\
\hline $\begin{array}{l}\text { I promote a balance of economic, social and environmental } \\
\text { concerns }\end{array}$ & I agree on maximizing the wealth of investors \\
\hline I promote a balance between social mission and social value & I believe that a social organization survives through profits \\
\hline I promote solutions that are ethical & I agree to make profits a means to achieve a social goal \\
\hline Entrepreneurial attitude (Armitage \& Conner, 1999) & Subjective Norms (Armitage \& Conner, 1999) \\
\hline Start my own business in the relatively near future ( 2 or 3 years) & People who are important to me think I should start a business \\
\hline would be: & $\begin{array}{l}\text { People who are important to me would approve that I start my own } \\
\text { business }\end{array}$ \\
\hline $\begin{array}{l}\text { Harmful-Beneficial } \\
\text { Unpleasant-Pleasant }\end{array}$ & People who are important to me want me to become an entrepreneur \\
\hline $\begin{array}{l}\text { Unenjoyable-Enjoyable } \\
\text { Foolish-Wise } \\
\text { Unnecessary-Necessary }\end{array}$ & $\begin{array}{l}\text { I feel under social pressure (from spouse, family, friends, partners) to } \\
\text { establish my own business }\end{array}$ \\
\hline
\end{tabular}


About the authors:

1. Judith Cavazos-Arroyo, PhD in Marketing, Universidad Popular Autónoma del Estado de Puebla.

E-mail: judith.cavazos@upaep.mx.

2. Rogelio Puente-Díaz, PhD in Psychology, Universidad Anáhuac México. E-mail: rogelio.puente@ anahuac.mx.

3. Nivedita Agarwal, PhD in Innovation \& Technology Management, Friedrich-Alexander-Universität Erlangen-Nürnberg. E-mail: nivedita.agarwal@fau.de.

\section{Contribution of each author:}

\begin{tabular}{|c|c|c|c|}
\hline Contribution & $\begin{array}{c}\text { Judith Cavazos- } \\
\text { Arroyo }\end{array}$ & $\begin{array}{c}\text { Rogelio } \\
\text { Puente-Díaz }\end{array}$ & $\begin{array}{r}\text { Nivedita } \\
\text { Agarwal } \\
\end{array}$ \\
\hline 1. Definition of research problem & $\sqrt{ }$ & & $\sqrt{ }$ \\
\hline 2. Development of hypotheses or research questions (empirical studies) & $\sqrt{ }$ & $\sqrt{ }$ & $\sqrt{ }$ \\
\hline 3. Development of theoretical propositions (theoretical Work ) & $\sqrt{ }$ & $\sqrt{ }$ & \\
\hline 4. Theoretical foundation/ Literature review & $\sqrt{ }$ & $\sqrt{ }$ & \\
\hline 5. Definition of methodological procedures & $\sqrt{ }$ & $\sqrt{ }$ & $\sqrt{ }$ \\
\hline 6. Data collection & $\sqrt{ }$ & & \\
\hline 7. Statistical analysis & & $\sqrt{ }$ & \\
\hline 8. Analysis and interpretation of data & & $\sqrt{ }$ & \\
\hline 9. Critical revision of the manuscript & $\sqrt{ }$ & $\sqrt{ }$ & $\sqrt{ }$ \\
\hline 10. Manuscript Writing & $\sqrt{ }$ & $\sqrt{ }$ & \\
\hline
\end{tabular}

